\title{
On the hydrolysis of diethyl 2-(perfluorophenyl)malonate
}

\author{
Ilya V. Taydakov ${ }^{*} 1,2$ and Mikhail A. Kiskin ${ }^{3}$
}

\author{
Letter \\ Address: \\ ${ }^{1}$ P.N. Lebedev Physical Institute of the Russian Academy of \\ Sciences. Leninskiy prospect, 53, Moscow, GSP-1, 119991, Russian \\ Federation, ${ }^{2}$ G.V. Plekhanov Russian University of Economics, \\ Stremyanny per. 36, Moscow, 117997, Russian Federation and ${ }^{3}$ N.S. \\ Kurnakov Institute of General and Inorganic Chemistry, Russian \\ Academy of Sciences, Leninskiy prospect, 31, Moscow, GSP-1, \\ 119991, Russian Federation \\ Email: \\ Ilya V. Taydakov* - taydakov@gmail.com \\ * Corresponding author \\ Keywords: \\ decarboxylation; fluorinated aromatic compounds; hydrolysis of \\ esters; 2-(perfluorophenyl)acetic acid; 2-(perfluorophenyl)malonic acid
}

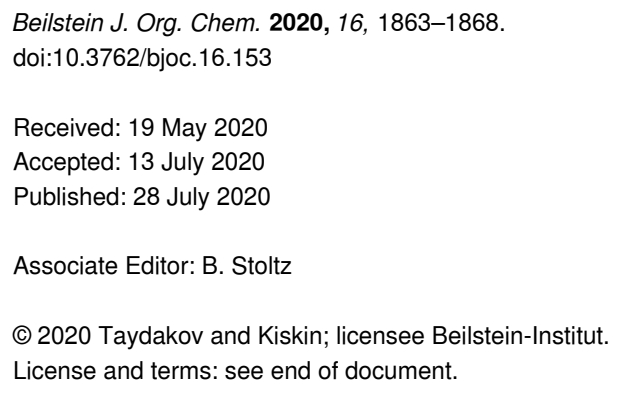

(C) 2020 Taydakov and Kiskin; licensee Beilstein-Institut. 
<smiles>O=C(O)C(C(=O)O)c1ccccc1</smiles>

1<smiles>O=C(O)C(C(=O)O)c1c(F)c(F)c(F)c(F)c1F</smiles>

2

Figure 1: Phenylmalonic acids.

diethyl 2-(perfluorophenyl)malonate (3) with excess $\mathrm{NaH}$ [21]. At the same time, diethyl 2-(perfluorophenyl)malonate (3) is a readily accessible compound. Diethyl 2-phenylmalonate (4) is usually obtained (Scheme 1) by condensation of ethyl phenylacetate (5) and diethyl carbonate under basic conditions [22] because of the low reactivity of bromobenzene in noncatalytic nucleophilic reactions with sodium salts of diethyl malonate (6) $[23,24]$.

In contrast with bromobenzene, hexafluorobenzene (7) is sufficiently reactive in nucleophilic substitution reactions, and thus the synthesis of 2-(perfluorophenyl)malonate (3) is straightforward. A synthesis of diethyl 2-(perfluorophenyl)malonate (3) was first described in patent literature [25]. The target compound was obtained by the reaction of diethyl malonate, $\mathrm{NaH}$ and $\mathrm{C}_{6} \mathrm{~F}_{6}$ in DMF for $5 \mathrm{~h}$ under reflux. This method was modi- fied by Vlasov et al. [26], then $\mathrm{NaH}$ was replaced [27] by anhydrous $\mathrm{K}_{2} \mathrm{CO}_{3}$ and the reaction temperature was decreased [28] to $60{ }^{\circ} \mathrm{C}$ (Scheme 2). Although the latter method claimed to give diethyl 2-(perfluorophenyl)malonate (3) in 92\% yield, it can hardly be scaled up due to the utilization of gradient column chromatography for the separation of the desired product. We obtained diethyl 2-(perfluorophenyl)malonate (3) in 47\% isolated yield by a modified method [26]. The product was isolated on $150 \mathrm{mmol}$ scale by simple vacuum distillation.

Hydrolysis of diethyl 2-(perfluorophenyl)malonate (3) unexpectedly turned out to be quite challenging. Unsubstituted diethyl or dimethyl 2-phenylmalonate can be readily hydrolyzed under basic conditions by heating with aqueous or mixed water-EtOH solutions [29] or in biphasic water- $\mathrm{Et}_{2} \mathrm{O}$ mixtures [30] under reflux conditions.

An exhaustive analysis of the literature revealed that virtually the same conditions were suitable for the hydrolysis of diethyl 2-(2,6-difluoro-4-methoxyphenyl)malonate (8) [31], dimethyl 2-(2-fluorophenyl)-2-methylmalonate (9) [32], diethyl 2-(3fluorophenyl)-2-methylmalonate (10) [33], and diethyl 2-(4fluorophenyl)malonate (11) [6,32] (Figure 2) with minor variations in the alkali concentration and temperature. No nucleophilic substitution of activated fluorine atoms or other side reactions were observed under the conditions mentioned above.

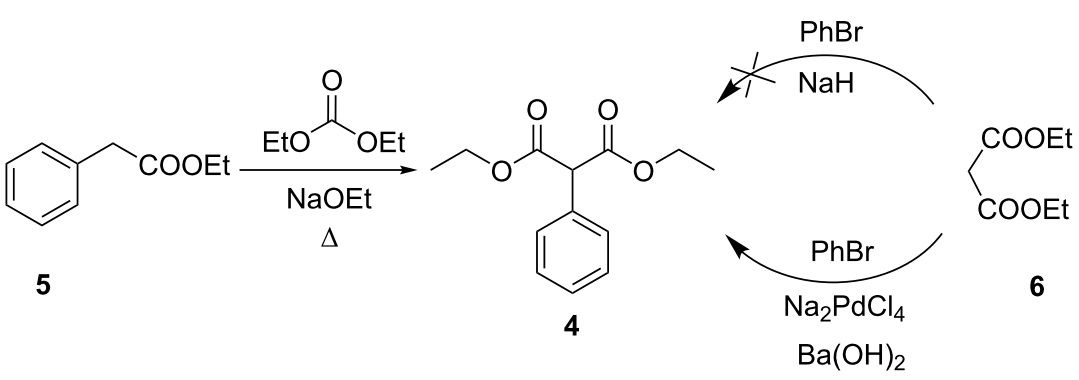

$\Delta$

Scheme 1: Synthesis of diethyl 2-phenylmalonate (4).

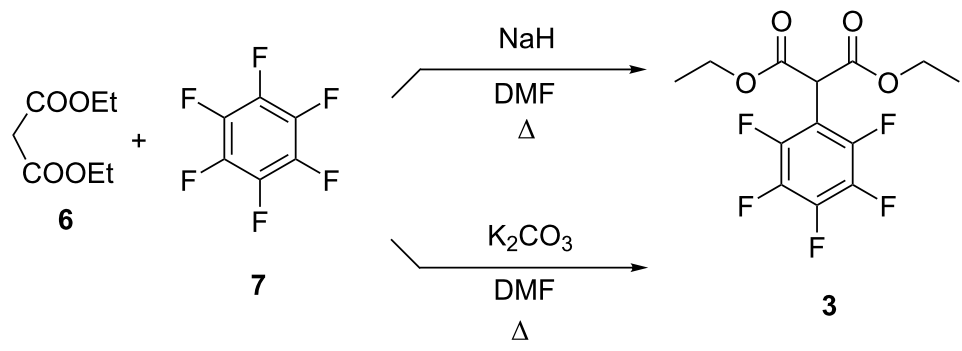

Scheme 2: Synthesis of diethyl 2-(perfluorophenyl)malonate (3). 
<smiles>CCOC(=O)C(C(=O)OCC)c1c(F)cc(OC)cc1F</smiles>

8<smiles>COC(=O)C(C)(C(C)=O)c1ccccc1F</smiles>

9<smiles>CCOC(=O)C(C)(C(=O)OCC)c1cccc(F)c1</smiles>

10<smiles>CCOC(=O)C(C(=O)OCC)c1ccc(F)cc1</smiles>

11

Figure 2: Esters of fluorine-substituted 2-phenylmalonic acids.

In preliminary experiments, we tested the mildest system biphasic $10 \% \mathrm{KOH}$ aqueous solution- $\mathrm{Et}_{2} \mathrm{O}$ at reflux temperature $\left(35^{\circ} \mathrm{C}\right)$ and vigorous agitation for the hydrolysis of diethyl 2-(perfluorophenyl)malonate (Scheme 3)<smiles>CCOC(=O)C(C(=O)OCC)c1c(F)c(F)c(F)c(F)c1F</smiles>

3

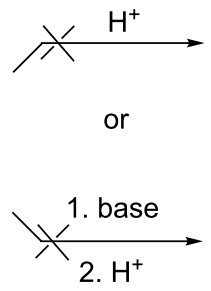<smiles>O=C(O)C(C(=O)O)c1c(F)c(F)c(F)c(F)c1F</smiles>

2
Scheme 3: Hydrolysis of diethyl 2-(perfluorophenyl)malonate (3).

No reaction occurred under these conditions after $5 \mathrm{~h}$ of refluxing. Increasing the alkali concentration up to $20 \%$ did not induce a reaction. Different reaction conditions and bases were used, and the results are summarized in Table 1.

In general, one can conclude that under mild reaction conditions (room temperature, biphase mixtures) the starting ester remained intact, while under drastic conditions (high concentration of alkali, homogeneous solutions, elevated temperatures), decomposition and/or decarboxylation occurred. However, it is possible that decarboxylation took place during the isolation of the free acid. In all cases, no desired malonic acid $\mathbf{2}$ was isolated from the reaction mixtures; the main part of the original material was recovered. In some experiments, variable amounts of 2-(perfluorophenyl)acetic acid (12) were obtained after acidification of the basic solution. Moreover, noticeable decomposition of $\mathbf{3}$ was observed along with the formation of acid 12. The nature of these byproducts was not analyzed. Probably, they are formed by nucleophilic substitution of fluorine atoms in the perfluorophenyl moiety.

\section{Table 1: Hydrolysis of 3 under basic conditions.}

Base Solvent(s)
Time, $\mathrm{h}$
Temperature, ${ }^{\circ} \mathrm{C}$ Yield of compound ${ }^{a}$<smiles>O=C(O)C(C(=O)O)c1c(F)c(F)c(F)c(F)c1F</smiles>

$\mathrm{KOH}$ (5 equiv)

$\mathrm{NaOH}$ (3 equiv)

$\mathrm{NaOH}$ (3 equiv)

$\mathrm{NaOH}$ (3 equiv)

$\mathrm{NaOH}$ (3 equiv)

$\mathrm{LiOH}$ (2 equiv)

$\mathrm{LiOH}$ (2 equiv)

$\mathrm{LiOH}$ (2 equiv)

$10 \% \mathrm{H}_{2} \mathrm{O}+\mathrm{Et}_{2} \mathrm{O}$
$20 \% \mathrm{H}_{2} \mathrm{O}+\mathrm{Et}_{2} \mathrm{O}$
$15 \% \mathrm{H}_{2} \mathrm{O}$
$15 \% \mathrm{H}_{2} \mathrm{O}$
$15 \% \mathrm{H}_{2} \mathrm{O}+\mathrm{EtOH}(1: 2 \mathrm{v} / \mathrm{v})$
$15 \% \mathrm{H}_{2} \mathrm{O}+\mathrm{EtOH}(1: 2 \mathrm{v} / \mathrm{v})$
dioxane
dioxane- $\mathrm{H}_{2} \mathrm{O}(10 \%)$
dioxane- $\mathrm{H}_{2} \mathrm{O}(10 \%)$

reflux (35)

reflux (35)

5

5

15

5

15

5

reflux (80)

1520

$15 \quad 20$

$5 \quad 80$
20

80

20

20
2<smiles>O=C(O)Cc1c(F)c(F)c(F)c(F)c1F</smiles>

12

$\begin{array}{cc}\text { n.d. }{ }^{b} & \text { n.d. } \\ \text { n.d. } & \text { n.d. } \\ \text { n.d. }{ }^{\mathrm{b}} & \text { n.d. } \\ \text { n.d. } & 12^{\mathrm{c}} \\ \text { n.d. }{ }^{\mathrm{b}} & \text { n.d. } \\ \text { n.d. } & 15^{\mathrm{b}} \\ \text { n.d. } & \text { n.d. } \\ \text { n.d. } & 11^{\mathrm{c}} \\ \text { n.d. } & 17^{\mathrm{c}}\end{array}$

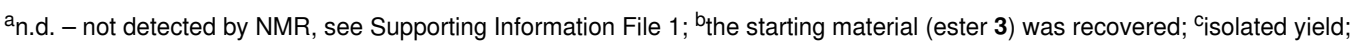


Acid $\mathbf{1 2}$ is fairly soluble in water and the separation of reaction products is cumbersome (see Supporting Information File 1). The structure of acid $\mathbf{1 2}$ in solid form was studied by single crystal X-ray diffraction experiments (Figure 3). The structural parameters were deposited at CCDC (deposit No. 1993963, see Supporting Information File 1 for details).

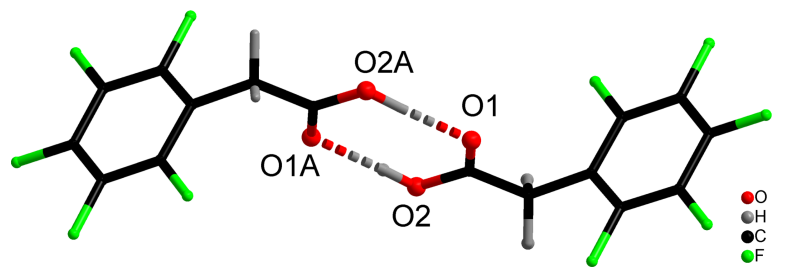

Figure 3: Molecular structure of 2-(perfluorophenyl)acetic acid (12).

Since basic conditions seem to be unsuitable for the hydrolysis of diethyl 2-(perfluorophenyl)malonate, acid-catalyzed reactions were also tested. Trifluoroacetic acid (TFA) is a common reagent for the catalytic cleavage of tert-butyl esters, but in the stoichiometric quantity it is also suitable for the cleavage of nonvolatile methyl or ethyl esters due to transesterification $[34,35]$. The removal of highly volatile methyl or ethyl trifluoroacetates from the reaction mixture is the driving force of this process. Unfortunately, 2-(perfluorophenyl)malonate does not react with excess TFA (up to 10 equivalents) even under reflux conditions, but in one experiment a catalytic amount of concentrated $\mathrm{H}_{2} \mathrm{SO}_{4}$ was added, and then coincidentally the reaction mixture was slightly overheated (to $100{ }^{\circ} \mathrm{C}$ ), which led to the evaporation of the entire acid. The remaining solid was identified as 2-(perfluorophenyl)acetic acid (12). We believe that 2-(perfluorophenyl)acetic acid might be formed by thermal decarboxylation of the desired 2-(perfluorophenyl)malonic acid. To prove this hypothesis, 2-(perfluorophenyl)malonate (3) was heated under reflux conditions with an excess of $48 \%$ aqueous $\mathrm{HBr}$ solution according to the method described in [36], but only traces of 2-(perfluorophenyl)acetic acid (12) were isolated after $16 \mathrm{~h}$ of reflux along with the unchanged original ester. In addition, considerable darkening of the biphase reaction mixture was observed. To overcome the problem of miscibility of the ester and acid, $\mathrm{AcOH}$ was used as a co-solvent. After some optimization of the reaction conditions, it was found that best results were achieved if a 1:5 v/v mixture of $48 \% \mathrm{HBr}$ and glacial $\mathrm{AcOH}$ was used. The starting ester is fully soluble in this mixture, and the reaction occurs in a homogeneous solution (Scheme 4).

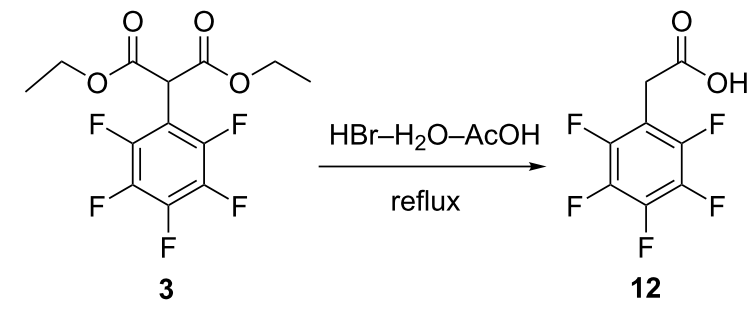

Scheme 4: Formation of 2-(perfluorophenyl)acetic acid (12)

Unfortunately, in all experiments hydrolysis was accompanied by complete decarboxylation, and only 2-(perfluorophenyl)acetic acid (12) was separated from the reaction mixtures. The results of the acidic hydrolysis are summarized in Table 2. It seems that 2-(perfluorophenyl)malonic acid (2) is unexpectedly thermally unstable, because as a rule, decarboxylation of other phenylmalonic acids with strong electronwithdrawing groups required much higher temperatures $\left(160-200{ }^{\circ} \mathrm{C}\right)$ or the presence of a catalyst $[31,37]$.

Table 2: Hydrolysis of $\mathbf{3}$ under acidic conditions.

Acid

Solvent(s)
Time, $\mathrm{h} \quad$ Temperature, ${ }^{\circ} \mathrm{C}$

\section{Yield of compound ${ }^{a}$}

212

n.d. ${ }^{b} \quad$ n.d.

n.d. ${ }^{b} \quad$ n.d.

n.d. ${ }^{b} \quad$ trace

n.d. ${ }^{b}$ trace

reflux

reflux $(75)+$ overheat $(100) \quad$ n.d. $\quad 35^{c}$

$100 \quad$ n.d. ${ }^{b} \quad 10^{c}$

20 n.d. ${ }^{b}$ n.d.

reflux (120) n.d. $63^{c}$

\footnotetext{
$a_{\text {n.d. }}$ - not detected by NMR, see Supporting Information File 1; ${ }^{b}$ the starting material (ester 3 ) was recovered; cisolated yield;
} 
However, acid-catalyzed hydrolysis of diethyl 2-(perfluorophenyl)malonate (3) can be used as a convenient, inexpensive and simple multigram approach to 2-(perfluoro-phenyl)acetic acid (12). This new method is shorter and much safer than the classical one based on the hydrolysis of 2-(perfluorophenyl)acetonitrile $[38,39]$, because utilization of both toxic 1-(bromomethyl)-2,3,4,5,6-pentafluorobenzene and alkali metal cyanides is avoided.

\section{Conclusion}

To summarize, we have extensively investigated the reactivity of diethyl 2-(perfluorophenyl)malonate (3) towards hydrolysis in acidic and basic media. It was revealed, that the ester is fairly stable in basic and acidic solutions at ambient temperatures and decompose to a mixture of products (2-(perfluorophenyl)acetic acid (12) was identified as a major product) at harsh basic conditions. Vigorous hydrolysis by a mixture of aqueous $\mathrm{HBr}$ and $\mathrm{AcOH}$ at reflux temperature led to the formation of 2-(perfluorophenyl)acetic acid (12) as single product in good preparative yield. Evidently, ethyl 2-(perfluorophenyl)malonate (3) is not suitable for the preparation of 2-(perfluorophenyl)malonic acid (2), due to its thermal instability and strong tendency to decarboxylation. We believed, that di-tert-butyl 2-(perfluorophenyl)malonate or dibenzyl 2-(perfluorophenyl)malonate, which are cleaving under very mild conditions are better precursors, but these esters are expensive, hardly accessible and can barely be used for large-scale preparation of 2-(perfluorophenyl)malonic acid (12).

\section{Supporting Information}

\section{Supporting Information File 1}

Detailed information about experimental procedures, X-ray diffraction experiments for compound $\mathbf{1 2}$ and characterization data for compounds $\mathbf{3}$ and $\mathbf{1 2}$. [https://www.beilstein-journals.org/bjoc/content/ supplementary/1860-5397-16-153-S1.pdf]

\section{Acknowledgements}

Single crystal X-ray diffraction analysis was performed using the equipment at the Centre for Collective Use of the Kurnakov Institute RAS, which operates with the support of the state assignment of the Kurnakov Institute RAS in the field of fundamental scientific research.

\section{Funding}

This work was financially supported by the Russian Science Foundation (Project №19-13-00272).

\section{ORCID ${ }^{\circledR}$ iDs}

Ilya V. Taydakov - https://orcid.org/0000-0001-9860-4141

\section{References}

1. Bui, M.; Hao, X.; Shin, Y.; Cardozo, M.; He, X.; Henne, K.; Suchomel, J.; McCarter, J.; McGee, L. R.; San Miguel, T.; Medina, J. C.; Mohn, D.; Tran, T.; Wannberg, S.; Wong, J.; Wong, S.; Zalameda, L.; Metz, D.; Cushing, T. D. Bioorg. Med. Chem. Lett. 2015, 25, 1104-1109. doi:10.1016/j.bmcl.2015.01.001

2. Ng, P. S.; Manjunatha, U. H.; Rao, S. P. S.; Camacho, L. R.; Ma, N. L.; Herve, M.; Noble, C. G.; Goh, A.; Peukert, S.; Diagana, T. T.; Smith, P. W.; Kondreddi, R. R. Eur. J. Med. Chem. 2015, 106, 144-156. doi:10.1016/j.ejmech.2015.10.008

3. Koryakina, I.; McArthur, J.; Randall, S.; Draelos, M. M.; Musiol, E. M.; Muddiman, D. C.; Weber, T.; Williams, G. J. ACS Chem. Biol. 2013, 8, 200-208. doi:10.1021/cb3003489

4. Zhang, W.; Holyoke, C. W., Jr.; Barry, J.; Cordova, D.; Leighty, R. M.; Tong, M.-H. T.; Hughes, K. A.; Lahm, G. P.; Pahutski, T. F.; Xu, M.; Briddell, T. A.; McCann, S. F.; Henry, Y. T.; Chen, Y. Bioorg. Med. Chem. Lett. 2017, 27, 911-917. doi:10.1016/j.bmcl.2017.01.002

5. Rivkin, A.; Kim, Y. R.; Goulet, M. T.; Bays, N.; Hill, A. D.; Kariv, I.; Krauss, S.; Ginanni, N.; Strack, P. R.; Kohl, N. E.; Chung, C. C.; Varnerin, J. P.; Goudreau, P. N.; Chang, A.; Tota, M. R.; Munoz, B. Bioorg. Med. Chem. Lett. 2006, 16, 4620-4623. doi:10.1016/j.bmcl.2006.06.014

6. Nascimento de Oliveira, M.; Arseniyadis, S.; Cossy, J. Chem. - Eur. J. 2018, 24, 4810-4814. doi:10.1002/chem.201800641

7. Ariyarathna, Y.; Tunge, J. A. Org. Biomol. Chem. 2014, 12, 8386-8389. doi:10.1039/c4ob01752h

8. Reddy Chidipudi, S.; Burns, D. J.; Khan, I.; Lam, H. W. Angew. Chem., Int. Ed. 2015, 54, 13975-13979. doi:10.1002/anie.201507029

9. Wang, Y.; Zhao, F.; Zhou, Y.; Chi, Y.; Wang, Z.; Zhang, W.-X.; Xi, Z. Chem. - Eur. J. 2013, 19, 10643-10654. doi:10.1002/chem.201301633

10. Petina, O.; Yakovlev, I.; Geffken, D. Synthesis 2013, 45, 803-809. doi:10.1055/s-0032-1316851

11. Elagawany, M.; Ibrahim, M. A.; Panda, S. S. Tetrahedron Lett. 2016, 57, 4910-4913. doi:10.1016/j.tetlet.2016.09.070

12. Zhu, M.; Cui, X.; Zhang, S.; Liu, L.; Han, Z.; Gao, E. J. Inorg. Biochem. 2016, 157, 34-45. doi:10.1016/j.jinorgbio.2016.01.016

13. Li, Z.-Y.; Xu, Y.-L.; Zhang, X.-F.; Zhai, B.; Zhang, F.-L.; Zhang, J.-J.; Zhang, C.; Li, S.-Z.; Cao, G.-X. Dalton Trans. 2017, 46, 16485-16492. doi:10.1039/c7dt03562d

14. Carter, A.; Mason, A.; Baker, M. A.; Bettler, D. G.; Changas, A.; McMillen, C. D.; Tapu, D. Organometallics 2017, 36, 1867-1872. doi:10.1021/acs.organomet.7b00206

15. Pasán, J.; Lago, A. B.; Cañadillas-Delgado, L.; Fabelo, Ó.; Ruiz-Pérez, C.; Lloret, F.; Julve, M. Polyhedron 2019, 170, 217-222. doi:10.1016/j.poly.2019.05.045

16. Pasán, J.; Sanchiz, J.; Fabelo, Ó.; Cañadillas-Delgado, L.; Déniz, M.; Díaz-Gallifa, P.; Martínez-Benito, C.; Lloret, F.; Julve, M.; Ruiz-Pérez, C. CrystEngComm 2014, 16, 8106-8118. doi:10.1039/c4ce00834k

17. Chichetti, S. M.; Ahearn, S. P.; Adams, B.; Rivkin, A. Tetrahedron Lett. 2007, 48, 8250-8252. doi:10.1016/j.tetlet.2007.08.134

18. Imao, D.; Itoi, A.; Yamazaki, A.; Shirakura, M.; Ohtoshi, R.; Ogata, K.; Ohmori, Y.; Ohta, T.; Ito, Y. J. Org. Chem. 2007, 72, 1652-1658. doi:10.1021/jo0621569 
19. Richardson, P. Expert Opin. Drug Discovery 2016, 11, 983-999. doi:10.1080/17460441.2016.1223037

20. Gerstenberger, M. R. C.; Haas, A. Angew. Chem., Int. Ed. Engl. 1981, 20, 647-667. doi:10.1002/anie.198106471

21. Vlasov, V. M.; Krivousova, E. D.; Yakobson, G. G. Zh. Org. Khim. 1970, 6, 758-767.

22. Wallingford, V. H.; Homeyer, A. H.; Jones, D. M. J. Am. Chem. Soc. 1941, 63, 2056-2059. doi:10.1021/ja01853a008

23. Semmes, J. G.; Bevans, S. L.; Mullins, C. H.; Shaughnessy, K. H. Tetrahedron Lett. 2015, 56, 3447-3450. doi:10.1016/j.tetlet.2015.01.072

24. Aramendıa, M. A.; Borau, V.; Jiménez, C.; Marinas, J. M.; Ruiz, J. R.; Urbano, F. J. Tetrahedron Lett. 2002, 43, 2847-2849. doi:10.1016/s0040-4039(02)00314-3

25. Hull, R. New pentafluorobenzene derivatives and processes for their manufacture. G.B. Patent 901880, July 25, 1962.

Chem. Abstr. 1963, 58, 8714.

26. Vlasov, V. M.; Yakobson, G. G. Zh. Obshch. Khim. 1969, 39, 785-787.

27. Pees, K. J. Pentafluorophenylazolopyrimidines. U.S. Patent US5,817,663, Oct 6, 1998. Chem. Abstr. 1999, 131, 257580.

28. Senaweera, S. M.; Weaver, J. D. J. Org. Chem. 2014, 79, 10466-10476. doi:10.1021/jo502075p

29. Fatiha, M.; Touati, A.; Rahal, S.; Moulay, S. Asian J. Chem. 2011, 2, 961-967.

30. Capaccio, V.; Sicignano, M.; Rodríguez, R. I.; Della Sala, G.; Alemán, J. Org. Lett. 2020, 22, 219-223. doi:10.1021/acs.orglett.9b04195

31. Woo, L. W. L.; Wood, P. M.; Bubert, C.; Thomas, M. P.; Purohit, A.; Potter, B. V. L. ChemMedChem 2013, 8, 779-799. doi:10.1002/cmdc.201300015

32. Miyamoto, K.; Tsuchiya, S.; Ohta, H. J. Fluorine Chem. 1992, 59 , 225-232. doi:10.1016/s0022-1139(00)82414-8

33. Leonard, K. A. Heteroaryl linked quinolinyl modulators of RORyt. U.S. Patent US2014107097, April 17, 2014.

Chem. Abstr. 2014, 160, 606703

34. Todo, Y.; Nitta, J.; Miyajima, M.; Fukuoka, Y.; Yamashiro, Y.; Nishida, N.; Saikawa, I.; Narita, H. Chem. Pharm. Bull. 1994, 42, 2063-2070. doi:10.1248/cpb.42.2063

35. Hutchinson, J. H. Autotaxin inhibitor compounds. WO Patent WO2015048301, April 2, 2015.

Chem. Abstr. 2014, 162, 501145

36. Kuchař, M.; Brunová, B.; Rejholec, V.; Roubal, Z.; Němeček, O. Collect. Czech. Chem. Commun. 1981, 46, 1173-1187. doi:10.1135/cccc19811173

37. Toussaint, O.; Capdevielle, P.; Maumy, M. Synthesis 1986, 1029-1031. doi:10.1055/s-1986-31861

38. Barbour, A. K.; Buxton, M. W.; Coe, P. L.; Stephens, R.; Tatlow, J. C. J. Chem. Soc. 1961, 808-817. doi:10.1039/jr9610000808

39. Birchall, J. M.; Haszeldine, R. N. J. Chem. Soc. 1961, 3719. doi:10.1039/jr9610003719

\section{License and Terms}

This is an Open Access article under the terms of the Creative Commons Attribution License (http://creativecommons.org/licenses/by/4.0). Please note that the reuse, redistribution and reproduction in particular requires that the authors and source are credited.

The license is subject to the Beilstein Journal of Organic Chemistry terms and conditions: (https://www.beilstein-journals.org/bjoc)

The definitive version of this article is the electronic one which can be found at:

doi:10.3762/bjoc. 16.153 